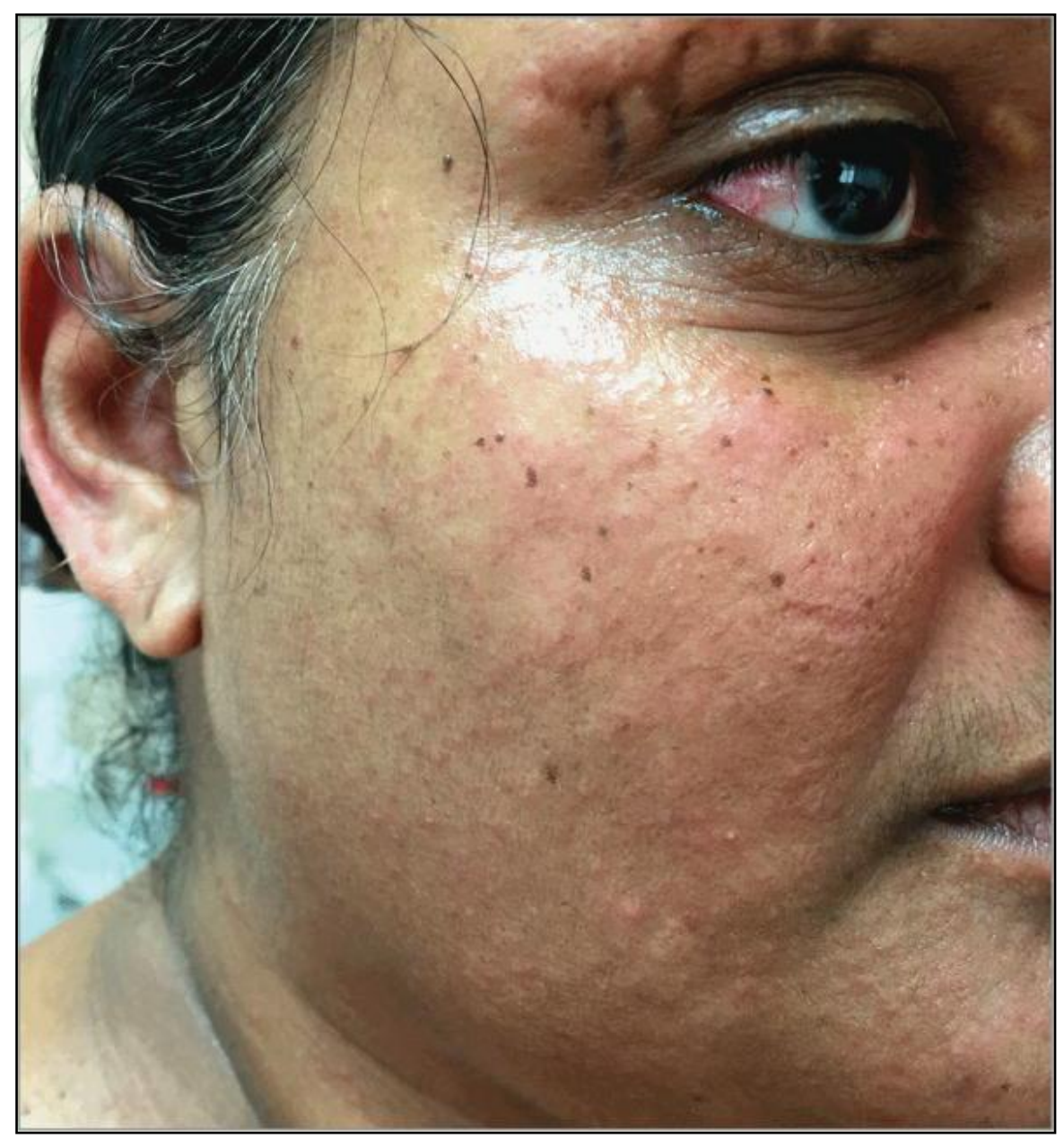

\title{
Main Characteristics of Zika Virus Exanthema in
}

Guadeloupe.

Cordel, Nadege; Birembaux, Xavier; Chaumont, Hugo;

Delion, Frederique; Chosidow, Olivier; Tressieres, Benoit;

Herrmann Storck, Cecile

JAMA Dermatology. 153(4):326-328, April 2017

DOI : 10.1001/jamadermatol.2016.5442

Zika Virus Exanthema in an Adult WomanFigure. . This case shows typical converging tiny red papules of the cheek associated with a conjunctival hyperemia.

\section{W. Wolters Kluwer} Health 